\title{
Mesenchymal stem cells for the treatment of systemic lupus erythematosus: is the cure for connective tissue diseases within connective tissue?
}

\author{
Flavio A Carrion ${ }^{1,2}$ and Fernando E Figueroa*1,2
}

\begin{abstract}
Mesenchymal stem cells (MSCs) are now known to display not only adult stem cell multipotency but also robust anti-inflammatory and regenerative properties. After widespread in vitro and in vivo preclinical testing in several autoimmune disease models, allogenic MSCs have been successfully applied in patients with severe treatment-refractory systemic lupus erythematosus. The impressive results of these uncontrolled phase I and II trials - mostly in patients with non-responding renal disease - point to the need to perform controlled multicentric trials. In addition, they suggest that there is much to be learned from the basic and clinical science of MSCs in order to reap the full potential of these multifaceted progenitor cells in the treatment of autoimmune diseases.
\end{abstract}

\section{Introduction}

Patients with systemic lupus erythematosus (SLE) remain at increased risk for premature death [1], particularly among young adults [2]. Up to $45 \%$ of cases present early end organ damage, related to persistent activity or kidney disease [3]. Renal involvement, which occurs in 40 to 50\% of patients in most series, is associated with mortality rates approximately eight times higher than expected [2], and remains only partially responsive to the best available treatments. Indeed, therapy with cyclophosphamide has not improved patient survival compared with corticosteroids [4], and the largest controlled trial comparing

\footnotetext{
*Correspondence: ffigueroa@uandes.cl

'Laboratorio de Inmunología Celular y Molecular, Facultad de Medicina, Universidad de los Andes, Avda San Carlos de Apoquindo 2200, Las Condes, Santiago 7620001, Chile

Full list of author information is available at the end of the article
}

mycophenolate mofetil with intravenous cyclophosphamide in lupus nephritis achieved complete remission in only $8.6 \%$ and $8.1 \%$ of patients, respectively [5]. Undoubtedly there is a need for safer and more effective treatments for SLE.

\section{Mesenchymal stem cells}

Mesenchymal stromal cells, originally described in the 1960s as bone forming cells in the bone marrow [6], are now called multipotent mesenchymal stromal cells, or more commonly mesenchymal stem cells (MSCs) since they display adult stem cell multipotency. Thus, they differentiate into bone, cartilage and other connective tissues [7]. Unlike hematopoietic stem cells, which originate from bone marrow, MSCs can also be isolated from a variety of other tissues, such as umbilical cord or adipose tissue, and can be extensively expanded in vitro by up to 50 cell doublings without differentiation [8]. While these properties initially put MSCs center stage of an alleged era of regenerative medicine, the unexpected findings of Bartholomew and colleagues in 2002 [9] pointed to new features of these progenitor cells, the consequences of which are still being revealed in several areas of medicine. MSCs were found to escape T-cell recognition, suppress $\mathrm{T}$-cell response to mitogens and also to prolong skin graft survival in baboons. In spite of a wide array of immunomodulatory effects that were subsequently proven to affect $\mathrm{T}$ and $\mathrm{B}$ lymphocytes, natural killer and antigen-presenting cells [10,11], MSCs remain hypoimmunogenic since they express low levels of major histocompatibility (MHC) class I molecules and do not express MHC class II or co-stimulatory (CD40, CD40L, CD80 or CD86) molecules [12]. Since the effects on immunocompetent cells are not MHC restricted, allogenic MSCs are widely used with no need to match them with host human leukocyte antigens (HLAs). The mechanisms underlying these effects are a subject of great scientific interest, as reviewed elsewhere in this issue, but apparently involve both cell contact and soluble 
factors, including indoleamine 2,3-dioxygenase, prostaglandin E2, nitric oxide, transforming growth factor (TGF)- $\beta 1$, IL-10, soluble HLA-G, and IL-1 receptor antagonists [13,14]. Also, several growth factors, such as hepatocyte growth factor, vascular endothelial growth factor (VEGF), insulin-like growth factor, epidermal growth factor, basic fibroblast growth factor and stromal cell-derived factor-1, among others, have been implicated in the modulatory and reparative effects of MSCs [15].

Recently, several studies have identified critical roles for microRNAs (miRNAs) involved in proliferation, migration and differentiation of MSCs, suggesting that they might play an important role in the acquisition of reparative MSC phenotypes [16].

\section{Therapeutic use of MSCs in autoimmune and inflammatory diseases}

Given their vast proliferative potential, extensive immunosuppressive properties, and also the ease of access to proper tissue sources, therapies with autologous or allogenic MSCs have been tested in a variety of immunemediated disease models, including experimental allergic encephalomyelitis $[17,18]$ - a model of multiple sclerosis diabetic NOD/SCID mice [19], collagen-induced arthritis [20,21], and several lupus murine models [22-28]. Results have been mainly encouraging, but not altogether consistent, particularly in the case of arthritis [29], and lupus mice $[26,27]$.

At the time of writing this review, 141 registered human trials on MSCs were found at the National Institutes of Health ClinicalTrials.gov website [30], including 13 for graft versus host disease (GVHD), 10 for diabetes, 7 for Crohn's disease or ulcerative colitis, 5 for multiple sclerosis, 2 for amyotrophic lateral sclerosis, one each for Sjögren syndrome and systemic sclerosis and two for SLE. Some of these trials point to non-immune-mediated conditions that are associated with tissue injury, such as hepatic cirrhosis, myocardial infarction or congestive heart failure. In several instances it has become apparent that MSCs are not necessarily replacing diseased tissues or differentiating into separate cell lineages, but seem to exert a complex pattern of trophic, regenerative and antiinflammatory effects [31,32].

In humans, the most studied application for MSCs is GVHD, a complication of hematopoietic stem cell transplantation in which donor $\mathrm{T}$ cells attack an immunocompromised and genetically disparate recipient [33]. In 2004, Le Blanc and colleagues [34] treated a 9-year-old boy with severe treatment-resistant acute GVHD of the gut and liver with third party haplo-identical motherderived MSCs. Clinical response was striking, with improvement of liver and intestinal function. The most recent placebo controlled trials confirmed the significant improvement in liver and gastrointestinal GVHD, but did not reach significance for durable complete responses or other primary endpoints [35].

\section{Mesenchymal stem cells in systemic lupus erythematosus}

Perhaps the most remarkable results for human MSC therapy are now emerging from the latest clinical trials in severe, treatment-refractory SLE [36,37]. While these are still small, uncontrolled and non-multicentric studies, the recent reports of successful MSC treatment in other inflammatory and scarring conditions that are typical of the SLE spectrum $[38,39]$ lend support to these notoriously favorable outcomes. These trials also highlight the need to advance the clinical science of stem cell therapy and underscore the challenge of identifying specific mechanisms of action, given the multi-tiered effects of cellular therapies in vivo [40].

While in the past the connective tissue was assigned a low rank among organized tissues, nowadays it seems to harbor far reaching properties. Undoubtedly, when Dr Paul Klemperer suggested that the histopathological connective tissue changes found in SLE were common to the 'obscure maladies that collectively are called diseases of the connective tissue or collagen diseases' [41], little did he know that a cure for such diseases might also be found within connective tissues!

\section{Animal models of disease}

While the MSCs derived from SLE patients and diseased mice are still immunosupressive in vitro [42], they are abnormal in terms of phenotype, proliferation and differentiation [43-45]. Sun and colleagues have forwarded the hypothesis that an impaired bone marrow MSC niche contributes to disease development in human [43] and murine SLE [23]. They describe in Fas-deficient MLR/lpr mice a significant osteoporosis phenotype with osteoclast activity and $\mathrm{T}$ cell over-activation that does not respond to cyclophosphamide treatment, but is corrected by MSC transplant [23]. Even if this assumed MSC deficiency is only a consequence of immune activation in SLE, this rationale has supported the use of allo- or xenogeneic instead of autologous - MSCs for the treatment of SLE [23]. For example, in MRL/lpr mice, allogenic mouse or human MSCs derived from bone marrow (BM-MSCs), umbilical cord (UC-MSCs) or exfoliated deciduous teeth have all been highly effective in reducing or even normalizing serum autoantibodies, proteinuria, renal pathology and survival of diseased animals [22-25]. In contrast, the NZB/W F1 strain, considered the murine model that most closely resembles human SLE, has shown diverging results. For example, human UC-MSCs delayed disease and alleviated lupus nephritis [27], while allogenic murine BM-MSCs (from C57BL/6J mice) did not affect proteinuria or double-stranded DNA (dsDNA) 
levels, but still improved renal function [28]. Surprisingly, BM-MSCs from another strain (BALB/c mice) had opposite effects, enhancing anti-dsDNA antibody production and worsening disease and kidney pathology [26].

\section{Human systemic lupus erythematosus}

Prompted by the positive results in the Fas-deficient MRL/lpr mice treated with human MSCs from healthy individuals [22], Sun and colleagues [23] treated four patients with active disease and lupus nephritis (24 hour urine protein $\geq 1 \mathrm{~g}$ and/or serum creatinine $\geq 1.5 \mathrm{mg} / \mathrm{dl}$ ) that was unresponsive to monthly intravenous cyclophosphamide $\left(0.75 \mathrm{~g} / \mathrm{m}^{2}\right)$ and oral prednisone $(\geq 20 \mathrm{mg} /$ day) for 6 months. All patients received one infusion of $\geq 1 \times 10^{6}$ BM-MSCs (from healthy family members) per kilogram of body weight. The Systemic Lupus Disease Activity Index (SLEDAI) at 1, 6 and 12 months follow-up improved significantly, as did urinary protein, and also CD4+ Foxp3+ T regulatory (Treg) cell counts at 3 months follow-up. Prednisone and cyclophosphamide were reduced, and the latter even suspended in two patients. None had complications after 12 to 18 months follow-up. These encouraging results led to a larger phase I open trial in 15 patients - including the first 4 cases reported with refractory disease as described above, except that one-third of patients had also failed oral mycophenolate mophetil (1 to $2 \mathrm{~g} /$ day for 3 months) [37]. All cases fulfilled the previously stated criteria for refractory renal disease except one with only refractory thrombocytopenia $\left(24 \times 10^{9} / \mathrm{L}\right)$. Non-renal manifestations included arthritis, severe skin disease, serositis and ten cases with non-responsive cytopenias. Patients received one intravenous infusion of $1 \times 10^{6}$ allogeneic BM-MSCs per kilogram body weight (harvested from passages 3 to 5 ) from non-HLA-matched healthy family members. Subsequently, steroids were reduced to 5 to $10 \mathrm{mg} /$ day maintaining lower dose cyclophosphamide $(0.4$ to $0.6 \mathrm{~g})$ for 2 to 3 months. Mean follow-up reached 17.2 (3 to 36) months with no adverse effects, deaths or ensuing GVHD. Clinical and serological changes were quite dramatic for this group of patients with severe disease as gauged by an average baseline SLEDAI of $12.1 \pm 3.3$, in spite of daily prednisone $(23 \pm 5 \mathrm{mg})$ and immunosuppressive drugs. In 12 patients SLEDAI again improved significantly, to $3.2 \pm 2.8$ at 12 months $(P<0.05)$, remaining under 8 in all patients and even zero in four patients. Only one subject was able to discontinue immunosuppressants, remaining with inactive disease at 12 months on $5 \mathrm{mg}$ daily prednisone. Two patients flared at 6 and 12 months, respectively. Quite surprisingly, 24 hour proteinuria $(2,538.0 \pm 382.3 \mathrm{mg}$ at baseline $)$ decreased significantly $(1,430.7 \pm 306.3 ; P<0.01, \mathrm{n}=12)$ as soon as one week after MSC therapy - even preceding changes in antidsDNA antibodies - and continued to improve thereafter until month 12. Glomerular filtration rate improved in two patients who had reduced values at study entry, as did creatinine levels in four subjects. Anti-dsDNA antibodies decreased significantly at 1 month $(P<0.05)$ and 3 months $(P<0.05)$ post-transplant. Treg cells, which have been found to be quantitatively and qualitatively deficient in active SLE $[46,47]$, were restored at week 1 (from $2.56 \pm 0.37$ to $4.58 \pm 0.51 ; P<0.05, \mathrm{n}=13$ ) as judged by the percentage of CD4+ Foxp3+ cells among peripheral blood mononuclear cells.

A second open trial from this group in Nanjing, China followed, reporting the use of UC-MSCs in severe lupus [36]. UC-MSCs are easily accessible, have high proliferative potential [48] and have been used with success in lupus mice [24]. Patients $(n=16)$ and entry criteria were similar to the previous study, though this time 5 of 15 renal cases had histological confirmation of proliferative nephritis, and 11 were preconditioned with cyclophosphamide (0.8 to $1.8 \mathrm{~g}$ intravenously) prior to MSC infusion. Subsequently, prednisone was reduced to 5 to $10 \mathrm{mg}$ every 2 weeks and patients were kept on maintenance cyclophosphamide ( 0.6 to $0.8 \mathrm{~g})$, which was able to be eventually discontinued in only three individuals. Mean follow-up was only 8.25 months. Significant improvement at 1 and/or 3 months was verified by SLEDAI score (two patients completed 2 years with scores <4), serum albumin, 24 hour urinary protein, serum creatinine (six patients), serum C3 (five patients) and antidsDNA antibodies. Baseline CD4+ Foxp3+ cells (Treg cells) increased significantly at 3 and 6 months, and a fall in serum IL-4 (with a non-significant increase of IFN- $\gamma$ ) was interpreted by the authors as indicative of improvement of pathogenic Th2 imbalance, though animal lupus models have shown the opposite cytokine change [27]. Finally, a case report from the group in Nanjing, but not from the realm of renal disease, draws further attention to the potency of MSC treatment: a 19-year-old girl with a recent diagnosis of SLE presented with massive diffuse alveolar hemorrhage unresponsive to methylprednisolone (160 mg/d for 4 days, $500 \mathrm{mg} / \mathrm{d}$ for 3 days) and intravenous immunoglobulin (20 g/day for 5 days) [49]. Repeated high-resolution chest computed tomography spanning 9 weeks showed diffuse bilateral alveolar infiltrates. After only one day of UC-MSC infusion $\left(2 \times 10^{6} / \mathrm{kg}\right.$ body weight) the patient's level of oxygen saturation rose from 71 to $91 \%$, and 5 days later mechanical respiratory support was removed. Nine days later high-resolution chest computed tomography showed complete resolution. Recurrent pulmonary disease 6 weeks after being discharged - while on prednisone, cyclophosphamide and cyclosporin A - again responded promptly to MSC retreatment. This dramatic case underscores the need to unravel the biological components underlying the clinical effects of MSCs. 


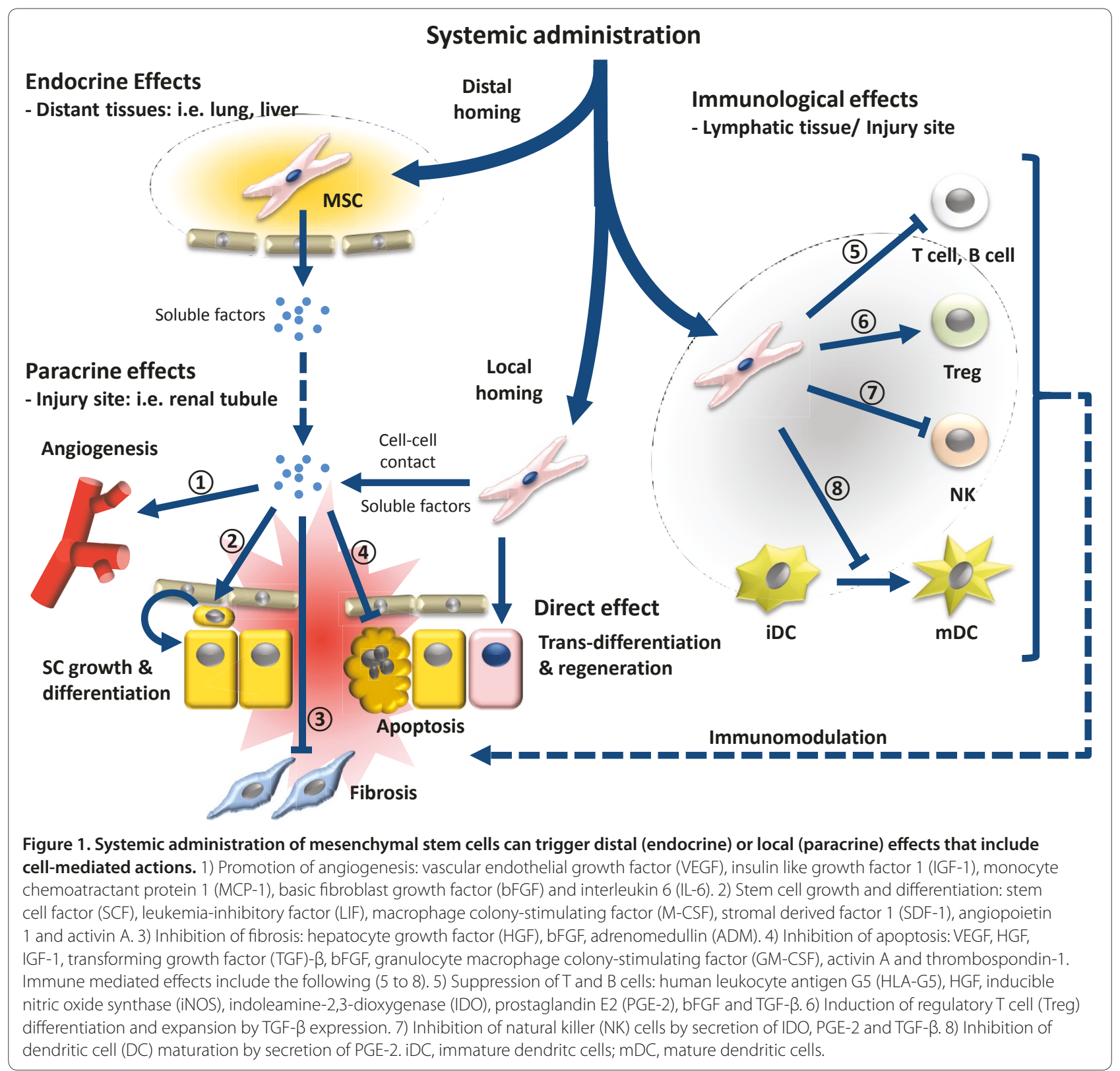

\section{Mechanisms of the therapeutic effects of MSC treatment}

Despite the in vitro and in vivo evidence for a therapeutic effect of MSCs in SLE, the mechanisms by which MSCs exert their immunomodulatory and reparative effects are still incompletely understood, but most likely involve multiple mechanisms (Figure 1).

\section{Proinflammatory 'licensing' of MSCs}

In contrast to therapies that cause global immune suppression, MSCs have been dubbed 'smart' immune modulators since their suppressive effects require a previous 'licensing' step that occurs in the presence of an inflammatory environment, and is mediated by the secretion of specific cytokines [50]. Thus, IFN- $\gamma$, alone or together with tumor necrosis factor- $\alpha$, IL- $1 \alpha$ or IL- $1 \beta$, are required to provoke the expression by MSCs of high levels of soluble factors involved in immunosuppression, such as indoleamine 2,3-dioxygenase, hepatocyte growth factor, TGF- $\beta 1$ and nitric oxide [51-54]. The need for this activation step has been confirmed in a model of GVHD since recipients of IFN- $\gamma^{-1-} \mathrm{T}$ cells did not respond to MSC treatment evolving into fatal GVHD [55].

\section{Tipping of the Th $1 /$ Th2 balance}

Although still controversial, an imbalance in IFN- $\gamma$ and IL-4 cytokine levels, suggestive of a pathogenic T helper 2 (Th2) response, has been reported in SLE. Accordingly, 
experimental data suggest that MSC therapy might ameliorate SLE by promoting the conversion from a Th2 humoral response to a Th1 cellular immune response through modulation of IL-4 and IFN- $\gamma$ levels in effector $\mathrm{T}$ cells. Zhou and colleagues [22] showed that intraperitoneal infusion of human BM-MSCs in MRL/lpr mice decreased the production of IL-4 and increased IFN- $\gamma$ in peripheral blood $\mathrm{T}$ cells. Sun and colleagues [36] reported similar findings with UC-MSC transplantation in patients with refractory SLE 3 months after treatment, also suggesting a polarization toward a Th1 phenotype that was associated with clinical improvement. However, Aggarwal and Pittenger [51] showed the opposite effect with the addition of human MSCs to differentiated effector T cells in vitro, and Chang and colleagues [27] found that UC-MSC transplantation in NZB/W $F_{1}$ mice was associated with an increase in the Th2 phenotype in the face of improving disease. The divergent results from these studies underline the complexity of both MSCmediated effects and the immunopathogenesis of SLE.

\section{Effects on CD4+ $\mathrm{T}$ cell populations: upregulation of Treg/Th17 ratio}

Several studies have provided evidence of a quantitative and/or qualitative defect of Treg cells in human SLE, as well as an increased production of Th17 proinflammatory cells $[46-47,56]$. On the other hand, MSCs have been shown to induce the generation of functional Treg cells both in vitro and in vivo $[21,57,58]$. In MLR/lpr mice, the transplantation of MSCs from many sources (bone marrow, umbilical cord or exfoliated deciduous teeth), can restore Treg cells and induce a significant reduction in Th17 levels, consequently up-regulating the ratio of Treg/Th17 cells [23-25]. In human SLE, the transplantation of either allogeneic or autologous MSCs derived from bone marrow or umbilical cord also increases Treg cells, suggesting that this may be one of the mechanisms of the MSC-mediated improvement of disease [23,36,37]. However, in two patients with active but not highly inflammatory SLE, we reported that the infusion of autologous MSCs induced no amelioration in spite of generating a marked increase in Treg cells [59].

\section{Mesenchymal stem cell homing and differentiation}

Long-term persistence of autologous or allogenic MSCs after a single intravenous infusion has been described in baboons, with levels of tissue engraftment ranging from 0.1 to $2.7 \%$ [60]. However, in a chronic kidney disease model, only repeated injections were associated with functional improvement and cortical entrapment of MSCs at 5 weeks [39]. In NZB/W F1 lupus mice treated with $1 \times 10^{6}$ human UC-MSCs via the tail vein, Chang and colleagues [27] could evidence MSCs in kidney tissues at week 2 of infusion, but no long-term engraftment.
Even if MSCs protect and improve recovery from several models of acute and chronic renal injury [61,62], paracrine and endocrine effects seem most important, since conditioned medium from MSCs has been able to mimic the beneficial effects of stem cell therapy [63]. The intricacy of such endocrine factors in vivo has been elegantly illustrated by Lee and colleagues [64] in a mouse model in which the reduced size of myocardial infarction in response to the infusion of human MSCs was due to the secretion of the anti-inflammatory protein TSG- 6 triggered by MSC entrapment in the lung.

\section{Gene expression and growth factors}

A number of genes and growth factors responsible for renal regeneration also seem to be involved in renal repair after the administration of MSCs [38]. High levels of angiogenic factors, such as VEGF, have been related to glomerulonephritis in SLE $[65,66]$, and Zhou and colleagues [22] showed that transplantation of human BM-MSCs in MRL/lpr mice reduced the expression of VEGF and TGF- $\beta$ and also deposits of fibronectin in glomeruli. In an ischemic model of chronic kidney disease we have shown that a single intravenous infusion of autologous MSCs triggers a significant increase in a group of nephrogenic proteins and transcription factors related to endothelial (VEGF and the angiopoietin-1 receptor Tie-2) and epithelial (bone morphogenetic protein-7, Pax-2, and basic fibroblast growth factor) differentiation, in association with a marked improvement of renal function [67].

Additionally, the importance of epigenetic regulatory factors in the control of biological processes and of the immune response has also been stressed. Common miRNA patterns of expression have been found in three different murine models of SLE [68], suggesting these might be targeted therapeutically. Since MSCs have been shown to secrete microparticles enriched in miRNAs [69], several authors have suggested that microvesiclemediated transfer of mRNA from MSCs to target tissues might also participate in some of the processes involved in immunoregulation or in the recovery from kidney injury in response to stem cell treatment [70].

\section{Conclusion}

The results of the first clinical trials with MSC therapy in severe SLE are undoubtedly encouraging. However, the heterogeneity of MSCs as defined today and the intricate circuitry of cellular and humoral factors that mediate their presently known effects still point to many issues to be resolved in order to pave the way for cell therapy in SLE. Long-term safety concerns remain an issue, given the description of in vitro malignant MSC transformation [71] and the unknown interaction of regular immunosupressants with single or repeated MSC therapy [72]. 
This article is part of a review series on Immunology and stem cells, edited by Christian Jorgensen. Other articles in the series can be found online at http://stemcellres.com/series/immunology

Along with the need for larger randomized controlled clinical trials, future advances from stem cell science can be expected to pinpoint significant MSC subpopulations and/or stem cell markers for regenerative or immunoregulatory properties, as well as specific mechanisms of action [73]. Thus, assays for in vitro or in vivo MSC potency could be developed, leading the way to the use of more potent stimulated or primed pre-treated MSCs.

\section{Abbreviations}

BM-MSC, bone marrow-derived mesenchymal stem cell; dsDNA, doublestranded DNA; GVHD, graft versus host disease; HLA, human leukocyte antigen; IFN, interferon; L, interleukin; MHC, major histocompatibility complex; miRNA, microRNA; MSC, mesenchymal stem cell; SLE, systemic lupus erythematosus; SLEDAI, Systemic Lupus Disease Activity Index; TGF, transforming growth factor; Th, T helper; Treg, T regulatory; UC-MSC, umbilical cord-derived mesenchymal stem cell; VEGF, vascular endothelial growth factor.

\section{Competing interests}

The authors declare that they have no competing interests.

\section{Authors' contributions}

Both authors contributed to the writing of the manuscript and read and approved the final version.

\section{Acknowledgements}

The authors thank Dr Felipe Alablaza for his contribution to the design of the figure. This work was supported by grant MED-004-7 from Universidad de los Andes and grant Innova Chile Corfo 205-4350.

\section{Author details}

'Laboratorio de Inmunología Celular y Molecular, Facultad de Medicina, Universidad de los Andes, Avda San Carlos de Apoquindo 2200, Las Condes, Santiago 7620001, Chile. PPrograma de Terapia Celular, Facultad de Medicina, Universidad de los Andes, Avda San Carlos de Apoquindo 2200, Las Condes, Santiago 7620001, Chile.

\section{Published: 11 May 2011}

\section{References}

1. Sacks JJ, Helmick CG, Langmaid G, Sniezek JE: Trends in deaths from systemic lupus erythematosus US 1979-1998. MMWR Morb Mortal Wkly Rep 2002, 51:371-374.

2. Bernatsky S, Boivin JF, Joseph L, Manzi S, Ginzler E, Gladman DD, Urowitz M, Fortin PR, Petri M, Barr S, Gordon C, Bae SC, Isenberg D, Zoma A, Aranow C, Dooley MA, Nived O, Sturfelt G, Steinsson K, Alarcón G, Senécal JL, Zummer M, Hanly J, Ensworth S, Pope J, Edworthy S, Rahman A, Sibley J, El-Gabalawy $\mathrm{H}$, McCarthy T, et al:: Mortality in systemic lupus erythematosus. Arthritis Rheum 2006, 54:2550-2557.

3. Nossent J, Kiss E, Rozman B, Pokorny G, Vlachoyiannopoulos P, Olesinska M, Marchesoni A, Mosca M, Påi S, Manger K, Schneider M, Nielsen H, van Vollenhoven R, Swaak T: Disease activity and damage accrual during the early disease course in a multinational inception cohort of patients with systemic lupus erythematosus. Lupus 2010, 19:949-956.

4. Illei GG, Austin HA, Crane M, Collins L, Gourley MF, Yarboro CH, Vaughan EM, Kuroiwa T, Danning CL, Steinberg AD, Klippel JH, Balow JE, Boumpas DT Combination therapy with pulse cyclophosphamide plus pulse methylprednisolone improves long-term renal outcome without adding toxicity in patients with lupus nephritis. Ann Intern Med 2001, 135:248-257.

5. Appel GB, Contreras G, Dooley MA, Ginzler EM, Isenberg D, Jayne D, Li LS, Mysler E, Sánchez-Guerrero J, Solomons N, Wofsy D: Aspreva Lupus Management Study Group. Mycophenolate mofetil versus cyclophosphamide for induction treatment of lupus nephritis. J Am SOC Nephrol 2009, 20:1103-1112.

6. Friedenstein AJ, Piatetzky-Shapiro II, Petrakova KV: Osteogenesis in transplants of bone marrow cells. J Embryol Exp Morphol 1966, 16:381-390.

7. Pittenger MF, Mackay AM, Beck SC, Jaiswal RK, Douglas R, Mosca JD, Moorman MA, Simonetti DW, Craig S, Marshak DR: Multilineage potential of adult human mesenchymal stem cells. Science 1999, 284:143-147.

8. Welter JF, Solchaga LA, Penick KJ: Simplification of aggregate culture of human mesenchymal stem cells as a chondrogenic screening assay. Biotechniques 2007, 42:732-737.

9. Bartholomew A, Sturgeon C, Siatskas M, Ferrer K, McIntosh K, Patil S, Hardy W, Devine S, Ucker D, Deans R, Moseley A, Hoffman R: Mesenchymal stem cells suppress lymphocyte proliferation in vitro and prolong skin graft survival in vivo. Exp Hematol 2002, 30:42-48.

10. Uccelli A, Moretta L, Pistoia V: Immunoregulatory function of mesenchymal stem cells. Eur I Immunol 2006, 36:2566-2573.

11. Tyndall A, Walker UA, Cope A, Dazzi F, De Bari C, Fibbe W, Guiducci S, Jones S, Jorgensen C, Le Blanc K, Luyten F, McGonagle D, Martin I, Bocelli-Tyndall C, Pennesi G, Pistoia V, Pitzalis C, Uccelli A, Wulffraat N, Feldmann M: Immunomodulatory properties of mesenchymal stem cells: a review based on an interdisciplinary meeting held at the Kennedy Institute of Rheumatology Division, London, UK, 31 October 2005. Arthritis Res Ther 2007, 9:301.

12. Chamberlain G, Fox J, Ashton B, Middleton J: Concise review: mesenchymal stem cells: their phenotype, differentiation capacity, immunological features, and potential for homing. Stem Cells 2007, 25:2739-2749.

13. Nauta AJ, Fibbe WE: Immunomodulatory properties of mesenchymal stromal cells. Blood 2007, 110:3499-3506.

14. Ghannam S, Bouffi C, Djouad F, Jorgensen C, Noël D: Immunosuppression by mesenchymal stem cells: mechanisms and clinical applications. Stem Cell Res Ther 2010, 1:2

15. Burdon T, Paul A, Noiseux N, Prakash S, Shum-Tim D: Bone marrow stem cell derived paracrine factors for regenerative medicine: current perspectives and therapeutic potential. Bone Marrow Res 2011. doi: 10.1155/2011/207326.

16. Tome M, López-Romero P, Albo C, Sepúlveda JC, Fernández-Gutiérrez B, Dopazo A, Bernad A, González MA: miR-335 orchestrates cell proliferation, migration and differentiation in human mesenchymal stem cells. Cell Death Differ 2010. doi:10.1038/cdd.2010.167.

17. Rafei M, Campeau PM, Aguilar-Mahecha A, Buchanan M, Williams P, Birman E, Yuan S, Young YK, Boivin MN, Forner K, Basik M, Galipeau J: Mesenchymal stromal cells ameliorate experimental autoimmune encephalomyelitis by inhibiting CD4 Th17 T cells in a CC chemokine ligand 2-dependent manner. J Immunol 2009, 182:5994-6002.

18. Bai L, Lennon DP, Eaton V, Maier K, Caplan Al, Miller SD, Miller RH: Human bone marrow derived mesenchymal stem cells induce Th2-polarized immune response and promote endogenous repair in animal models of multiple sclerosis. Glia 2009, 57:1192-1203.

19. Lee RH, Seo MJ, Reger RL, Spees JL, Pulin AA, Olson SD, Prockop DJ: Multipotent stromal cells from human marrow home to and promote repair of pancreatic islets and renal glomeruli in diabetic NOD/SCID mice. Proc Natl Acad Sci U S A 2006, 103:17438-17443.

20. Augello A, Tasso R, Negrini SM, Cancedda R, Pennesi G: Cell therapy using allogeneic bone marrow mesenchymal stem cells prevents tissue damage in collagen-induced arthritis. Arthritis Rheum 2007, 56:1175-1186.

21. González MA, Gonzalez-Rey E, Rico L, Büscher D, Delgado M: Treatment of experimental arthritis by inducing immune tolerance with human adipose-derived mesenchymal stem cells. Arthritis Rheum 2009, 60:1006-1019

22. Zhou $K$, Zhang H, Jin O, Feng $X$, Yao G, Hou Y, Sun L: Transplantation of human bone marrow mesenchymal stem cell ameliorates the autoimmune pathogenesis in MRL/lpr mice. Cell Mol Immunol 2008, 5:417-424.

23. Sun L, Akiyama K, Zhang H, Yamaza T, Hou Y, Zhao S, Xu T, Le A, Shi S: Mesenchymal stem cell transplantation reverses multiorgan dysfunction in systemic lupus erythematosus mice and humans. Stem Cells 2009, 27:1421-1432.

24. Gu Z, Akiyama K, Ma X, Zhang H, Feng X, Yao G, Hou Y, Lu L, Gilkeson GS, Silver RM, Zeng X, Shi S, Sun L: Transplantation of umbilical cord mesenchymal stem cells alleviates lupus nephritis in MRL/lpr mice. Lupus 2010, 19:1502-1514.

25. Yamaza T, Kentaro A, Chen C, Liu Y, Shi Y, Gronthos S, Wang S, Shi S: 
Immunomodulatory properties of stem cells from human exfoliated deciduous teeth. Stem Cell Res Ther 2010, 1:5.

26. Youd M, Blickarz C, Woodworth L, Touzjian T, Edling A, Tedstone J, Ruzek M, Tubo R, Kaplan J, Lodie T: Allogeneic mesenchymal stem cells do not protect NZBxNZW F1 mice from developing lupus disease. Clin Exp Immunol 2010, 161:176-186.

27. Chang JW, Hung SP, Wu HH, Wu WM, Yang AH, Tsai HL, Yang LY, Lee OK: Therapeutic effects of umbilical cord blood-derived mesenchymal stem cell transplantation in experimental lupus nephritis. Cell Transplant 2010. doi: $10.3727 / 096368910 \times 520056$.

28. Schena F, Gambini C, Gregorio A, Mosconi M, Reverberi D, Gattorno M, Casazza S, Uccelli A, Moretta L, Martini A, Traggiai E: Interferon- $\gamma$-dependent inhibition of $B$ cell activation by bone marrow-derived mesenchymal stem cells in a murine model of systemic lupus erythematosus. Arthritis Rheum 2010, 62:2776-2786.

29. Schurgers E, Kelchtermans H, Mitera T, Geboes L, Matthys P: Discrepancy between the in vitro and in vivo effects of murine mesenchymal stem cells on T-cell proliferation and collagen-induced arthritis. Arthritis Res Ther 2010, 12:R31.

30. ClinicalTrials.gov [http://clinicaltrials.gov/ct2/results?term=msc]

31. Block GJ, Ohkouchi S, Fung F, Frenkel J, Gregory C, Pochampally R, DiMattia G, Sullivan DE, Prockop DJ: Multipotent stromal cells are activated to reduce apoptosis in part by upregulation and secretion of stanniocalcin-1. Stem Cells 2009, 27:670-681.

32. Chen L, Tredget EE, Wu PY, Wu Y: Paracrine factors of mesenchymal stem cells recruit macrophages and endothelial lineage cells and enhance wound healing. PLoS One 2008, 3:e1886.

33. English K, French A, Wood KJ: Mesenchymal stromal cells: facilitators of successful transplantation? Cell Stem Cell 2010, 7:431-442.

34. Le Blanc K, Rasmusson I, Sundberg B, Götherström C, Hassan M, Uzunel M, Ringdén O: Treatment of severe acute graft-versus-host disease with third party haploidentical mesenchymal stem cells. Lancet 2004, 363:1439-1441.

35. Osiris Therapeutics Announces Preliminary Results for Prochymal Phase III GVHD Trials [http://investor.osiris.com/releasedetail.cfm?releaselD $=407404$ ]

36. Sun L, Wang D, Liang J, Zhang H, Feng X, Wang H, Hua B, Liu B, Ye S, Hu X, Xu W, Zeng X, Hou Y, Gilkeson GS, Silver RM, Lu L, Shi S: Umbilical cord mesenchymal stem cell transplantation in severe and refractory systemic lupus erythematosus. Arthritis Rheum 2010, 62:2467-2475.

37. Liang J, Zhang H, Hua B, Wang H, Lu L, Shi S, Hou Y, Zeng X, Gilkeson GS, Sun $L:$ Allogenic mesenchymal stem cells transplantation in refractory systemic lupus erythematosus: a pilot clinical study. Ann Rheum Dis 2010, 69:1423-1429.

38. Tögel FE, Westenfelder C: Mesenchymal stem cells: a new therapeutic tool for AKI. Nat Rev Nephrol 2010, 6:179-183.

39. Lee SR, Lee SH, Moon JY, Park JY, Lee D, Lim SJ, Jeong KH, Park JK, Lee TW, Ihm CG: Repeated administration of bone marrow-derived mesenchymal stem cells improved the protective effects on a remnant kidney model. Ren Fail 2010, 32:840-848.

40. Singer NG, Caplan Al: Mesenchymal stem cells: mechanisms of inflammation. Annu Rev Pathol Mech Dis 2011, 6:457-478.

41. Klemperer P: The concept of connective tissue diseases. Circulation 1962 , 25:869-871

42. Bocelli-Tyndall C, Bracci L, Spagnoli G, Braccini A, Bouchenaki M, Ceredig R, Pistoia V, Martin I, Tyndall A: Bone marrow mesenchymal stromal cells (BM-MSCs) from healthy donors and auto-immune disease patients reduce the proliferation of autologous- and allogeneic-stimulated lymphocytes in vitro. Rheumatology (Oxford) 2007, 46:403-408.

43. Sun LY, Zhang HY, Feng XB, Hou YY, Lu LW, Fan LM: Abnormality of bone marrow-derived mesenchymal stem cells in patients with systemic lupus erythematosus. Lupus 2007, 16:121-128.

44. Nie Y, Lau C, Lie A, Chan G, Mok M: Defective phenotype of mesenchymal stem cells in patients with systemic lupus erythematosus. Lupus 2010, 19:850-859

45. El-Badri NS, Hakki A, Ferrari A, Shamekh R, Good RA: Autoimmune disease: is it a disorder of the microenvironment? Immunol Res 2008, 411:79-86.

46. La Cava A: T-regulatory cells in systemic lupus erythematosus. Lupus 2008, 17:421-425.

47. Valencia X, Yarboro C, Illei G, Lipsky PE: Deficient CD4+CD25high T regulatory cell function in patients with active systemic lupus erythematosus. J Immunol 2007, 178:2579-2588.

48. Lu LL, Liu YJ, Yang SG, Zhao QJ, Wang X, Gong W, Han ZB, Xu ZS, Lu YX, Liu D,
Chen ZZ, Han ZC: Isolation and characterization of human umbilical cord mesenchymal stem cells with hematopoiesis-supportive function and other potentials. Haematologica 2006, 91:1017-1026.

49. Liang J, Gu F, Wang H, Hua B, Hou Y, Shi S, Lu L, Sun L: Mesenchymal stem cell transplantation for diffuse alveolar hemorrhage in SLE. Nat Rev Rheumatol 2010, 6:486-489.

50. Jones S, Horwood N, Cope A, Dazzi F: The antiproliferative effect of mesenchymal stem cells is a fundamental property shared by all stromal cells. J Immunol 2007, 179: 2824-2831.

51. Aggarwal S, Pittenger MF: Human mesenchymal stem cells modulate allogeneic immune cell responses. Blood 2005, 105:1815-1822.

52. Ryan JM, Barry F, Murphy JM, Mahon BP: Interferon-gamma does not break, but promotes the immunosuppressive capacity of adult human mesenchymal stem cells. Clin Exp Immunol 2007, 149:353-363.

53. Krampera M, Cosmi L, Angeli R, Pasini A, Liotta F, Andreini A, Santarlasci V, Mazzinghi B, Pizzolo G, Vinante F, Romagnani P, Maggi E, Romagnani S, Annunziato $F$ : Role for interferon-gamma in the immunomodulatory activity of human bone marrow mesenchymal stem cells. Stem Cells 2006, 24:386-398.

54. Ren G, Zhang L, Zhao X, Xu G, Zhang Y, Roberts Al, Zhao RC, Shi Y: Mesenchymal stem cellmediated immunosuppression occurs via concerted action of chemokines and nitric oxide. Cell Stem Cell 2008, 2:141-150.

55. Polchert D, Sobinsky J, Douglas G, Kidd M, Moadsiri A, Reina E, Genrich K, Mehrotra S, Setty S, Smith B, Bartholomew A: IFN-gamma activation of mesenchymal stem cells for treatment and prevention of graft versus host disease. Eur I Immunol 2008, 38:1745-1755.

56. Crispín JC, Tsokos GC: Interleukin-17-producing T cells in lupus. Curr Opin Rheumatol 2010, 22:499-503.

57. Prevosto C, Zancolli M, Canevali P, Zocchi MR, Poggi A: Generation of CD4+ or CD8+ regulatory T cells upon mesenchymal stem cell-lymphocyte interaction. Haematologica 2007, 92:881-888.

58. Gonzalez-Rey E, Gonzalez MA, Varela N, O'Valle F, Hernandez-Cortes P, Rico L, Büscher D, Delgado M: Human adipose-derived mesenchymal stem cells reduce inflammatory and $T$ cell responses and induce regulatory $T$ cells in vitro in rheumatoid arthritis. Ann Rheum Dis 2010, 69:241-248.

59. Carrion F, Nova E, Ruiz C, Diaz F, Inostroza C, Rojo D, Mönckeberg G, Figueroa FE: Autologous mesenchymal stem cell treatment increased T regulatory cells with no effect on disease activity in two systemic lupus erythematosus patients. Lupus 2010, 19:317-322.

60. Devine SM, Cobbs C, Jennings M, Bartholomew A, Hoffman R: Mesenchymal stem cells distribute to a wide range of tissues following systemic infusion into nonhuman primates. Blood 2003, 101:2999-3001.

61. Humphreys BD, Bonventre JV: Mesenchymal stem cells in acute kidney injury. Annu Rev Med 2008, 59:311-325

62. Choi S, Park M, Kim J, Hwang S, Park S, Lee Y: The role of mesenchymal stem cells in the functional improvement of chronic renal failure. Stem Cells Dev 2009, 18:521-529.

63. Bi B, Schmitt R, Israilova M, Nishio H, Cantley LG: Stromal cells protect against acute tubular injury via an endocrine effect. J Am Soc Nephrol 2007 18:2486-2496.

64. Lee RH, Pulin AA, Seo MJ, Kota DJ, Ylostalo J, Larson BL, Semprun-Prieto L, Delafontaine P, Prockop DJ: Intravenous hMSCs improve myocardial infarction in mice because cells embolized in lung are activated to secrete the anti-inflammatory protein TSG-6. Cell Stem Cell 2009, 5:54-63.

65. Robak E, Woźniacka A, Sysa-Jedrzejowska A, Stepień H, Robak T: Serum levels of angiogenic cytokines in systemic lupus erythematosus and their correlation with disease activity. Eur Cytokine Netw 2001, 12:445-452.

66. Navarro C, Candia-Zúñiga L, Silveira LH, Ruiz V, Gaxiola M, Avila MC, Amigo MC: Vascular endothelial growth factor plasma levels in patients with systemic lupus erythematosus and primary antiphospholipid syndrome. Lupus 2002, 11:21-24

67. Villanueva S, Ewertz E, Carrión F, Tapia A, Vergara V, Céspedes C, Saez P, Luz P, Irarrázabal C, Carreño JE, Fiqueroa F, Vio C: Mesenchyaml stem cells treatment induces functional and morphological improvement in chronic renal failure model in rats. Clin Sci 2011, in press.

68. Dai R, Zhang Y, Khan D, Heid B, Caudell D, Crasta O, Ahmed SA: Identification of a common lupus disease-associated microRNA expression pattern in three different murine models of lupus. PLoS One 2010, 5:e14302.

69. Chen TS, Lai RC, Lee MM, Choo AB, Lee CN, Lim SK: Mesenchymal stem cell secretes microparticles enriched in pre-microRNAs. Nucleic Acids Res 2010 
38:215-224

70. Camussi G, Deregibus MC, Tetta C: Paracrine/endocrine mechanism of stem cells on kidney repair: role of microvesicle-mediated transfer of genetic information. Curr Opin Nephrol Hypertens 2010, 19:7-12.

71. Miura M, Miura Y, Padilla-Nash HM, Molinolo AA, Fu B, Patel V, Seo BM, Sonoyama W, Zheng JJ, Baker CC, Chen W, Ried T, Shi S: Accumulated chromosomal instability in murine bone marrow mesenchymal stem cells leads to malignant transformation. Stem Cells 2006, 24:1095-1103.

72. Spaeth EL, Dembinski JL, Sasser AK, Watson K, Klopp A, Hall B, Andreeff M, Marini F: Mesenchymal stem cell transition to tumor-associated fibroblasts contributes to fibrovascular network expansion and tumor progression. PLoS One 2009, 4:e4992.
73. Psaltis PJ, Paton S, See F, Arthur A, Martin S, Itescu S, Worthley SG, Gronthos S, Zannettino AC: Enrichment for STRO-1 expression enhances the cardiovascular paracrine activity of human bone marrow-derived mesenchymal cell populations. J Cell Physio/ 2010, 223:530-540.

doi:10.1186/scrt64

Cite this article as: Carrion FA, Figueroa FE: Mesenchymal stem cells for the treatment of systemic lupus erythematosus: is the cure for connective tissue diseases within connective tissue? Stem Cell Research \& Therapy 2011 , $2: 23$. 